\title{
The implications of TARGET2 in the European balance of payments crisis and beyond
}

\author{
Sergio Cesaratto*
}

Full Professor of Economics of Growth and Development and of Fiscal and Monetary Policies of the European Union, Università di Siena, Italy

The paper provides an account of the meaning and implications of TARGET2 in the eurozone (EZ) balance of payments crisis. In this context, it discusses Hans-Werner Sinn's thesis about a stealth bail-out of the EZ periphery by the ECB from a heterodox perspective. Financial liberalisation, a relatively loose monetary policy and the provisional fading of devaluation risks generated ephemeral growth in some peripheral EZ countries sustained by capital flows from core countries. This has been followed by real exchange rate revaluation and deterioration of foreign accounts. As a result, external financing flows dried up and the previous stock of loans began to be repatriated. TARGET2 has played a fundamental role in avoiding a precipitous crisis. This distinguishes the European crisis from more traditional balance of payments crises. However, the presence of TARGET2 does not offset the absence of the financial crisis prevention and resolution mechanisms that are characteristic of fully fledged political and currency unions.

Keywords: European Monetary Union, financial crisis, Germany, neo-mercantilism, balance of payment, capital flows, sudden stops, TARGET2, OMT

JEL codes: $E 11, E 12, E 42, E 58, F 32, F 33, F 34, F 36, N 24$

\section{INTRODUCTION}

In 2011, Werner Sinn raised the question of the role of the European payment system TARGET2 (TransEuropean Automated Real-time Gross Settlement Express Transfer System, hereafter T2) in the eurozone (EZ) crisis. ${ }^{1}$ Despite some pro-German bias in his arguments, the profession should be grateful for this contribution. In the last 2 years, the debate has progressively made economists more aware of the workings of payment systems in the context of monetary policies. In this paper, I provide an account of the workings, economic meaning and implications of $\mathrm{T} 2$ in the context of the eurosystem and of the EZ crisis. In this regard, I will refer to the Classical-Kaleckian interpretation of the EZ crisis as a balance of payments (BoP) crisis (Cesaratto/Stirati 2010; Cesaratto 2011,

* I thank Eladio Febrero, V. Ramanan and two referees for comments, and Giancarlo Bergamini for help in improving the exposition.

1. The seminal prescient contribution on $\mathrm{T} 2$ is, however, by another German economist, Peter Garber (1998).

Received 25 April 2013, accepted 12 August 2013 
2013a, 2013b; Lucarelli 2012). Briefly, this interpretation maintains that, through financial liberalisation, a relatively loose monetary policy and provisional fading of devaluation risks associated to mercantilist behaviour of more competitive members, the European Monetary Union (EMU) has generated ephemeral growth in some peripheral EZ countries sustained by capital flows from core countries. Similar to past standard financial crises in emerging economies (Bordo/James 2013; Frenkel 2013), this sequence of events has been followed by real exchange rate revaluation and deterioration of foreign accounts. As a result, external financing flows dried up and the previous stock of loans began to be repatriated. At this stage, T2 began to play a fundamental role in avoiding a precipitous BoP crisis. This certainly distinguishes the EZ crisis from more traditional financial crises, although not to the point of invalidating its interpretation as a distinctive BoP crisis, as argued by some scholars who claim that there cannot be a BoP crisis in a currency union (CU). Indeed, T2 is a surrogate for the federal financial crisis prevention and resolution mechanisms that are characteristic of fully fledged political and currency unions (such as the US).

As analytical benchmarks, Section 2 describes international payments in a fixed exchange rate regime (FERR), and Section 3 compares the views of the late Fernando Vianello with those of Randall Wray on the possibility of a BoP crisis in a CU. Section 4 describes the operation of T2 before and after the crisis, comparing it to the International Clearing Union (ICU) proposed by Keynes. Section 5 dwells on the debate about the factual origin of T2 imbalances, current account (CA) deficits and capital flight, showing that this juxtaposition is misleading. The functioning of a payment system like T2 cannot be separated from other aspects of monetary system operation. In this respect, Section 6 points out that T2 imbalances and the ECB liquidity-providing operations - refinancing operations (RO) for short - are two sides of the same coin, and discusses the combination of T2 and RO in relation to the banking and sovereign debt crises. Section 7 discusses Sinn's reading of T2 as a stealth bail-out of the periphery. Consideration of the working of payment and refinancing operations also enriches understanding of the financial mechanisms behind the onset of BoP crises from Classical-Kaleckian and endogenous-money (Lavoie 2005) viewpoints. In this regard, Section 8 shows that the discussion about $\mathrm{T} 2$ proves that endogenous money theory is more useful than loanable fund theory in explaining the nature of international capital flows and therefore the dynamics of the EZ financial crisis. Section 9 deals with the fate of T2 imbalances in the case of euro break-up. The paper concludes in Section 10 with a summary of the main results. ${ }^{2}$

\section{INTERNATIONAL PAYMENTS IN A FIXED EXCHANGE RATE REGIME}

It is controversial whether there can be a BoP crisis in a CU. Of course, in principle, BoPs can be recorded in a CU for any member region. Whether it makes sense to keep track of them depends on the characteristics of the CU. Typical prototypes are the EZ and the US. Both are composed of economically dissimilar member states. The former is a 'trade-based' currency union, basically a free-trade area with a common currency. ${ }^{3}$ The second is a full federal union, endowed with a federal budget along with local state

2. Please use this introduction as a memo of most of the acronyms and abbreviations used in this paper.

3. The EU budget is a mere 1 per cent of EU GDP. Moreover, a substantial share of fiscal transfers has been diverted to poorer new extra-EZ members. This has also contributed to EZ CA imbalances (Holinski et al. 2012: 12). 
budgets, and with a full banking union. ${ }^{4}$ Barba/De Vivo (2013) call them flawed CU and viable $\mathrm{CU}$, respectively. One specific difference between the two unions is that in the former a return to national currency is theoretically possible, albeit difficult, once the in/out cost-benefit balance tilts in favour of the 'out' option. This is unthinkable in the second, where political will and institutions sustain a no-secession bias. A flawed CU is closer to a FERR than to a viable CU, and there are no signs that the EZ is evolving in that direction. To understand the dynamics of its crisis, it is therefore helpful to take FERR as a benchmark.

Within a FERR, the settlement of international payments takes place in an internationally accepted currency (reserve currency). ${ }^{5}$ This means that a CA deficit must be financed either by depleting foreign reserves or by obtaining foreign loans. As Cecchetti et al. (2012: 5) explain, in a 'typical textbook balance of payments crisis[, w] hen a country starts to experience a capital flow reversal arising from some combination of a loss of investor confidence and an attack on its currency, the outflows are limited by the size of the country's foreign exchange reserves. Once its reserves are exhausted, the country is forced to adjust.' The adjustment consists of a devaluation of the national currency accompanied, if the foreign debt is mainly denominated in foreign currencies, by a default due to the impossibility to service and repay the debt. The adjustment is thus followed by foreign debt restructuring, typically under IMF supervision. IMF loans are used to meet the most urgent payments, while the rest of the debt is re-profiled. The IMF also normally demands fiscal retrenchment to obtain a CA surplus and hence the capacity to service and repay the foreign debt in the long run, including the debt to the IMF. Currency devaluation usually mitigates the adjustment.

International payments in a FERR can be illustrated as in Figures 1 and 2, in which country A finances a foreign payment using its own foreign exchange reserves and through an international loan, respectively. ${ }^{6}$ Supposing, for simplicity, that both countries use a third country currency as the settlement money, the payment of customer 1 of country A to customer 2 of country B - say for an import - implies that country A is losing foreign reserves in favour of country B. Ceteris paribus, this payment will worsen the net international investment position (net IIP) of country A, which loses a stock of assets (foreign reserves), improving that of country B. Of course, these variations reflect the change (ceteris paribus) in the current account. In the case of Figure 1, the payment involves the transfer of reserves in foreign currency. Payments between central banks (CBs) may, for instance, take place through the Bank for International Settlements that acts as CB for CBs (Carrión Álavarez 2013).

Crucially, after the payment, Commercial Bank A is short of reserves. This can be recreated by the $\mathrm{CB}$ through an $\mathrm{RO}$ - a loan to Commercial Bank A - and is unproblematic. According to the theory of endogenous money, 'loans create deposits while the latter create reserves' (for example, Lavoie 2005). However, there is a limit to the amount of credit that monetary policy can permit and it depends on the availability of

4. In this regard, Gros (2012a; 2012b) notes the importance, in genuine federal states, of nationwide banks that can spread their local losses on the national network, while the difficulties of local banks are tackled by the federal, not by local, government. By contrast, in the EZ, the fear of a euro breakup has led some big EZ banks (for example, BNP Paribas) to withdraw support from their local troubled branches (for example, BNL), forcing them to rely on the ECB liquidity provision (Cecioni/Ferrero 2012: 20, fn.18; Cecchetti et al. 2012: 9-10; ECB 2013a: 107-108).

5. In the opposite extreme case of pure floating exchange rates, movements of the exchange rate take care of the $\mathrm{BoP}$.

6. A simple example of a domestic payment system is given in Cesaratto (2013b). 
362 European Journal of Economics and Economic Policies: Intervention, Vol. 10 No. 3

\begin{tabular}{|l|l|}
\hline \multicolumn{2}{|c|}{ Central Bank country A } \\
\hline Assets & Liabilities \\
\hline Foreign reserves & Reserves Bank A \\
\hline Loan to Bank A & Reserves \\
\hline
\end{tabular}

\begin{tabular}{|l|l|}
\hline \multicolumn{2}{|c|}{ Commercial Bank country A } \\
\hline Assets & Liabilities \\
\hline Reserves & Deposit customer 1 \\
\hline Reserves & Loan from the CB \\
\hline
\end{tabular}

\begin{tabular}{|l|l|}
\hline \multicolumn{2}{|c|}{ Commercial Bank country B } \\
\hline Assets & Liabilities \\
\hline Reserves & Deposit customer 2 \\
\hline
\end{tabular}

\begin{tabular}{|l|l|}
\hline \multicolumn{2}{|c|}{ Central Bank country B } \\
\hline Assets & Liabilities \\
\hline Foreign reserves & Reserves Bank B \\
\hline
\end{tabular}

Figure 1 International payments in a fixed exchange rate regime using foreign exchange reserves

\begin{tabular}{|l|l|}
\hline \multicolumn{2}{|c|}{ Commercial Bank country A } \\
\hline Assets & Liabilities \\
\hline Loan to customer 1 & Deposit customer 1 \\
Deposit at Bank B & Loan from Bank B \\
\hline Loan to customer 1 & Deposit to \\
Deposit at Bank B & Loan from Bank B \\
\hline
\end{tabular}

\begin{tabular}{|l|l|}
\hline \multicolumn{2}{|c|}{ Commercial Bank country B } \\
\hline Assets & Liabilities \\
\hline Loan to Bank A & Deposit of Bank A \\
\hline Loan to Bank A & $\begin{array}{l}\text { Deposit of Bank A } \\
\text { Deposit customer 2 }\end{array}$ \\
\hline
\end{tabular}

Figure 2 International payments in a fixed exchange rate regime using a foreign loan

foreign reserves (the case of foreign loans is considered shortly). Suppose, for instance, that credit is used in an open economy to finance the autonomous components of aggregate demand (AD). For a given marginal propensity to import and level of exports, there is only one level of credit-financed autonomous spending consistent with a given level of official reserves. The available international liquidity therefore limits the level and growth of national income - what is called foreign constraint. ${ }^{7}$ This limit can be relaxed by foreign loans, but not eliminated in the long run.

7. This condition recalls the Harrod-Thirlwall foreign trade-multiplier. 
Alternatively, Bank A may finance the payment by obtaining a loan from Bank B, as shown in Figure 2. We suppose in this case that the payment is denominated in the currency of the exporting country B. Call this currency DM. Suppose Bank A grants a loan to customer 1, an importer of a good from customer 2 in country B, opening a deposit (an overdraft) in her favour. When customer 1 makes the DM-denominated payment, Bank A asks Bank B for a loan in DM that it uses to make the payment that ends up as a deposit of customer 2 in Bank B. In this example, there is no movement of foreign reserves, since country A borrows in foreign currency to make the payment. Also, in this case, the net IIP of country B worsens and its foreign liabilities increase, while the net IIP of country B improves and its foreign claims rise. Foreign imbalances, however, may lead to downward pressure on currency A, and if it threatens to move out of a target range (narrow or otherwise), the central bank of country A may sell foreign currency on international markets. The amount of official reserves therefore limits the amount of payments that can be financed while preserving a given exchange rate.

\section{CAN THERE BE A BALANCE OF PAYMENTS CRISIS IN A CURRENCY UNION?}

The need to finance a CA deficit with foreign currencies seems to disappear in a CU. But does the foreign constraint evaporate with it, or does it reappear in a different form? Before a technical illustration of international payments in the EZ operated through T2, let us consider whether or not the concept of national BoPs within the $\mathrm{CU}$ is an empty concept (also in view of the existence of systems like T2).

In a CU, banks may grant loans in the common currency to trustworthy customers in any member country, confident that the $\mathrm{CB}$ will provide the necessary reserves. These loans can be employed, directly or indirectly, to make payments to other countries without any need to resort to official reserves or foreign loans. ${ }^{8}$ This ability is independent of whether the region in which the loan is accorded has its CA in surplus or deficit. On the other hand, in a FERR the capacity to sustain autonomous spending by creating loans is limited by available official reserves or the ability to obtain foreign loans. Does this mean an absence of foreign constraints for CU members? The answer seems to be no, as any economic unit must be solvent in the long run. Vianello discussed this question in a paper written with Anna Simonazzi just before the inception of the EMU (Simonazzi/Vianello 1999). The two authors were not yet fully aware of forthcoming Eurosystem payment mechanisms (TARGET followed by TARGET2). However, they allude to the fact that in a CU, as in a national payment system, international payments take place through the transfer of bank reserves - that is, high-powered money - and that by definition these reserves can be recreated by Eurosystem national central banks (NCBs) in deficit countries (and sterilised in surplus countries), just as the CB does in a monetarily independent country when the interbank loan market breaks down:

We suppose ... that the liquidity is spontaneously redistributed within the European banking system or, alternatively, that the creation of liquidity in surplus countries and its destruction

8. Note that it is not necessary for a loan to be specifically granted to finance a foreign payment. Whenever a loan finances some autonomous expenditure, in parallel to the Keynesian multiplier process, the deposit changes hands (Dalziel 1996) and part of it is used to finance imports (depending on the marginal propensity to import), see Section 7 below. 
in deficit countries are totally sterilised by national central banks. In this case, financing the deficit of an EMU member with respect to another will not pose problems greater than those posed, within a country, by financing the deficit of one region against another. (ibid.: 244-245, my translation).

Simonazzi/Vianello point out that inter-regional payments in a CU are not limited by the amount of international reserves in the vaults of the single region (in the case of the EMU, in those of the NCBs), or by obtaining foreign loans. This is because the CB of the deficit country can recreate the reserves lost in the international payments through an RO ('destruction [of liquidity] in deficit countries [is] totally sterilised by national central banks'). This is peculiar to a CU. While I shall later delve into these mechanisms, with Simonazzi/Vianello it is important to note that, although the power of banks to finance imports in a deficit country is not restrained by the available foreign currency, nonetheless a restraint still 'obviously' exists, 'represented by the will of households and firms to become indebted and of their trustworthiness as debtors' (as Simonazzi/Vianello point out in the mimeo version of their paper).

In a national economy (or in a viable $\mathrm{CU}$ ), the external foreign constraint means that inter-regional foreign constraints may be relaxed through fiscal transfers (ibid.: 245-246). Hence fiscal transfers, as they occur in a viable CU, modify the net import capacity of local regions, something that does not happen in a flawed currency union, such as the EMU. Fiscal transfers obviously cannot completely remove regional 'capacity (and will) to become indebted', they can only relax the external constraint (ibid.: 245).

In the absence of common banking surveillance mechanisms, in the EMU experience, as in countries under a FERR and financial liberalisation (Frenkel 2013; Cesaratto 2013a), 'the will of the households and firms to become indebted' and the eagerness of lenders have been encouraged (for example, Fahrholz/Freytag 2012: 9-10). Construction bubbles in certain peripheral countries, not the alleged profligacy of the member governments, led to the EZ financial crisis, although the crisis and the bail-out of banks eventually affected the sovereign finances of the EZ periphery. The possible initial illusory confidence of borrowers and lenders, followed later by increasing insolvency risk and disillusionment is presciently noted by Simonazzi/Vianello:

$[\mathrm{M}]$ onetary unification eliminates one of the two causes of interest rate spreads, that is, exchange rate risk, but not the other, linked to trustworthiness of debtors. If markets sometimes seem to forget this, it depends on the (usually justified) confidence of big operators in their ability to get out of the market in time ... A heavily indebted country that wants to avoid austerity policy may therefore enjoy phoney credibility for a certain period, allowing it to borrow at cheap rates, but it will not escape judgement day, and the later it comes, the harder it will be. Financial speculation, unable to target exchange rates, concentrates on the sovereign bond market, determining a fall in bond prices, making servicing of debt unsustainable and exposing the country to risk of insolvency. In the market word goes round that the country would be better off leaving the currency union and using inflation as a way out of its difficulties; these rumours aggravate the crisis, giving credibility to the rumours. (Simonazzi/ Vianello 1999: 247, my translation)

In other words, the almost unthinkable in the American federal CU is thinkable in the EZ flawed CU, namely countries turning insolvency risk into devaluation risk or 'convertibility risk' as Mario Draghi defines it (ECB 2013b).

On the other hand, Randall Wray and some of his Modern Monetary Theory (MMT) fellows seem to deny that the EZ is suffering a BoP crisis (Cesaratto 2013a: 120-122). In one post, for instance, Wray (2012) maintains that, although the EZ and US crises have 
analogies (for example, construction bubbles in some member states), nobody talks of a BoP crisis in the US case. Yet Wray's narrative of the EZ crisis is not fundamentally different from that provided by Simonazzi/Vianello in the preceding quotation. In addition, Wray fully acknowledges that the EZ lacks the substantial fiscal transfer institutions that relax the foreign constraint of weaker members in a genuine federal state (see Kaldor 1971 and Godley 1992 for early denunciation of this shortcoming). Being short of these mechanisms, financial liberalisation and the temporary availability of cheap foreign credit for countries with a biting foreign constraint may explain the 'sequence of unfortunate events' (Reinhart 2012) that led to the huge foreign imbalances of the EZ (like typical past events in emerging economies).

After the crisis erupted, the EMU also lacked the crisis resolution mechanisms that in viable CUs prevent emergence of convertibility risk due to the spectre of union break-up. Both Simonazzi/Vianello and Wray acknowledge that the Eurosystem payment and refinancing mechanisms, on which I focus here, apparently relaxed or hid the most evident manifestation of forthcoming crisis as occurs in a FERR: scarcity of international currency to make payments once capital flows dry up. Thus the system did not suddenly collapse when new financing stopped and foreign capital began to be withdrawn by not rollingover the debt. What a currency union cannot hide is the growing indebtedness of certain peripheral members in the absence of bank and local state crisis resolution mechanisms. As Simonazzi/Vianello and Wray suggest, when markets realise this, the affected states, burdened by their own banks' debts and deprived of monetary sovereignty, see their sovereign spreads rise, aggravating their solvency and the likelihood of exit from the monetary union, especially if austerity measures make things worse (an aspect repeatedly emphasised by De Grauwe/Ji 2013). ${ }^{9}$

Perhaps the difference between Simonazzi/Vianello and Wray lies in their respective perspectives. If one looks at the EMU through European lenses, one sees it as a collection of independent states with a currency in common and the crisis as a BoP crisis, albeit with some idiosyncrasies related to the monetary union. If one looks at the EMU through American lenses, one sees a flawed federal state with an irreversible commitment to the $\mathrm{CU}$ and the financial crisis appears due to the absence of adequate federal prevention and resolution mechanisms. If the EZ were a viable federal union, there would be no such crisis, the American argues. The disenchanted Eurosceptic replies that the EZ is not a full federal union and is unlikely to evolve in that direction. Thus, the first perspective seems more realistic and the EZ crisis closer to a traditional BoP crisis. ${ }^{10}$

The main message of this section can be summed up as follows. A weak region in a flawed CU that sees its external debt-GDP ratio deteriorating, will generate doubts about the solvency of its constituent states and banks. In a viable CU this is less likely to happen, given the inter-regional redistributive and prevention mechanisms, and the

9. For instance, Simonazzi/Vianello (1999: 245) presciently asked: 'If the deficit countries are always the same, the debts of the central banks [actually T2 liabilities, see below] of those countries will have increasing weight in the portfolio of the European Central Bank. Would the ECB (and surplus countries) allow such a process to continue indefinitely? We assume so, since no limit is officially indicated, although we share the doubts put forward by Kenen ... in this regard'. (This quotation is from the slightly more elaborate mimeo edition of the paper; my translation).

10. As a symmetric alternative to a full federal union, Wray and his MMT fellows seem to believe that full monetary sovereignty including floating exchange rates (no-commitment to convertibility at a fixed exchange rate) would also solve the foreign constraint, even in countries that do not issue an international currency. I have criticised this view in my exchanges with Wray (see Cesaratto 2012a; 2012b; 2012c; 2012d; and Ramanan 2012a). 
fact that a regional crisis would lead to adjustment action at federal level. This does not imply unlimited fiscal bail-out, of course, but simply that the burden of crises does not weigh only on troubled regions. The lack of these measures in a flawed CU may make exit from the $\mathrm{CU}$ a better option for deficit countries than deflationary measures to restore external solvency through obtainment of a CA surplus. Deflationary measures are not only socially painful, but also uncertain in their outcome in the absence of currency devaluation, which facilitates adjustment in a FERR. As a result, on the one hand, expectations of CU break-up raise sovereign spreads, making adjustment even harder; on the other hand, the monetary mechanisms of CUs delay full development of the crisis. The existence of such mechanisms keeps the EZ in an austerity limbo between break-up and an unlikely evolution to a viable union. Let us now look at these mechanisms.

\section{INTERNATIONAL PAYMENTS IN A CURRENCY UNION}

Since the operation of T2 has been explained by many authors, ${ }^{11}$ I will limit myself to a basic description (adapted from Cesaratto 2013b). Consider the Eurozone and Eurosystem (ECB plus the NCBs). Typically, a peripheral bank (say Santander) loses deposits in favour of a core EZ bank (say Deutsche Bank, DB) because of (Spanish) CA imbalances (for example, more payments are made for imports than are received from exports) or, increasingly since 2011, because of capital flight from the periphery to core Europe.

Step 1. Suppose Santander transfers a deposit (€100) to Deutsche Bank (DB). This is done through T2, the interbank payment system of the EZ: as in domestic systems, transfers between commercial banks are made by reserve transfer through the central bank; in the EZ they are made through the Eurosystem (as in Figure 3). Santander asks the Bank of Spain (BoS) to pay DB (€100). The BoS asks the ECB to credit $(€ 100)$ to the Bundesbank (BuBa). The latter finally credits $(€ 100)$ to DB. When BuBa creates reserves $(€ 100)$ in favour of $\mathrm{DB}$ (a liability for $\mathrm{BuBa}$ ), it matches the liability with a T2 claim $(€ 100)$ on the ECB. The ECB, in turn, matches the liability to BuBa with a claim $(€ 100)$ on BoS (a T2 liability for BoS), which finally matches this liability with a claim (or a fall in existing liabilities) (€100) on Santander.

Step 2 (ante-crisis case). As in domestic systems, when it has received a payment from Santander, DB has acquired reserves $(€ 100)$, while Santander has lost reserves $(€ 100)$. Normally, DB lends the excess reserves $(€ 100)$ to Santander (which is in general more profitable than leaving them idle in its reserve account at $\mathrm{BuBa}){ }^{12}$ In this

11. The list includes: Cecchetti et al. (2012); Cecioni/Ferrero (2012); Febrero/Uxò (2013); Whelan (2013a).

12. $€ 100$ is an approximation, since the DB now has more deposits and therefore needs more reserves, while the opposite is true for Santander. As explained by Febrero/Uxò (2013: 4-5), DB will normally lend the excess reserves to Santander at a rate close to the CB target interest rate (currently 0.75 per cent in the EZ). Santander could in principle borrow the necessary reserves from the Bank of Spain at a refinancing rate (currently 1.5 per cent in the EZ - that is, 0.75 per cent over the target rate) higher than that prevailing in the inter-bank market. At the same time, $\mathrm{DB}$ could deposit the excess reserves at $\mathrm{BuBa}$, but at a rate (currently 0 per cent in the $\mathrm{EZ}$ - that is, 0.75 per cent below the target rate) that would be punitive compared to the one prevailing on the inter-bank market. So the ECB creates mutual convenience for the commercial banks to lend each other the excess reserves at a rate that approximates the ECB target rate, according to the logic of the so-called interest rate corridor. This shows the link between the payment system and monetary policy. Of course, once the inter-bank market is broken, transmission of monetary policy becomes less effective - that is, the CB is unable to determine the short-term inter-bank loan 


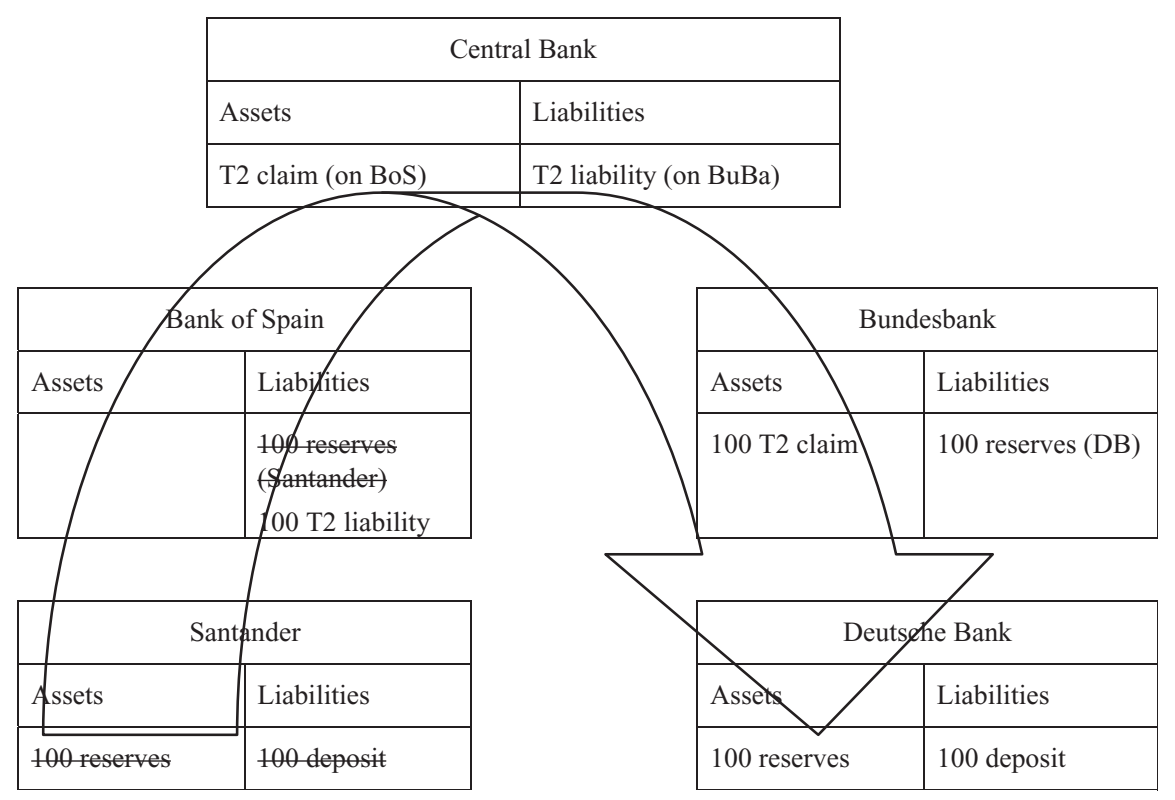

Figure 3 Operation of TARGET2 - step 1

case, the reserves travel through T2 in the opposite direction to step 1, clearing the T2 claim/liability positions of the two CBs (as in Figure 4). That is, when DB lends part of its reserves $(€ 100)$ to Santander, BuBa correspondingly cancels some liabilities $(€ 100)$ to DB and loses part of its T2 claims $(€ 100)$ on the ECB. Simultaneously, Santander sees its reserve account at the BoS replenished $(+€ 100)$; BoS sees its liabilities to Santander increase $(+€ 100)$, but having received a transfer via $\mathrm{T} 2$, it can cancel part of its previous T2 liabilities (-€100). So the 'official' T2 BoS liability towards the BuBa claim is cleared, replaced by 'private' liability of Santander towards DB. This worked until the crisis. T2 balances were roughly in equilibrium; of course, the net international investment positions (IIP) within the EZ were not, but they consisted of private loans. ${ }^{13}$

Step 2 (post-crisis case). However, suppose that the EZ interbank loan market breaks down, as it has since about 2008. In this case, T2 still allows Santander to transfer a deposit to DB (be it a payment for an import from Germany, or a German withdrawal of private financial investment in Spain). In either case, Santander cannot recover the lost reserves via a loan from DB. So the T2 imbalances are not cancelled out by a private transaction in the opposite direction (as in step 2 (ante-crisis case) above). At this point, BoS replenishes Santander's reserve account (with $€ 100$ ) through a short or long term RO available in the Eurosystem, managed by NCBs (see Figure 5).

interest rates and obtain the convergence of interest rates within the CU. To avoid the break-up of the payment system, however, the CB will supply all the necessary liquidity to keep the system running.

13. As recalled below, $\mathrm{T} 2$ claims and liabilities are part of the IIP of a country. 


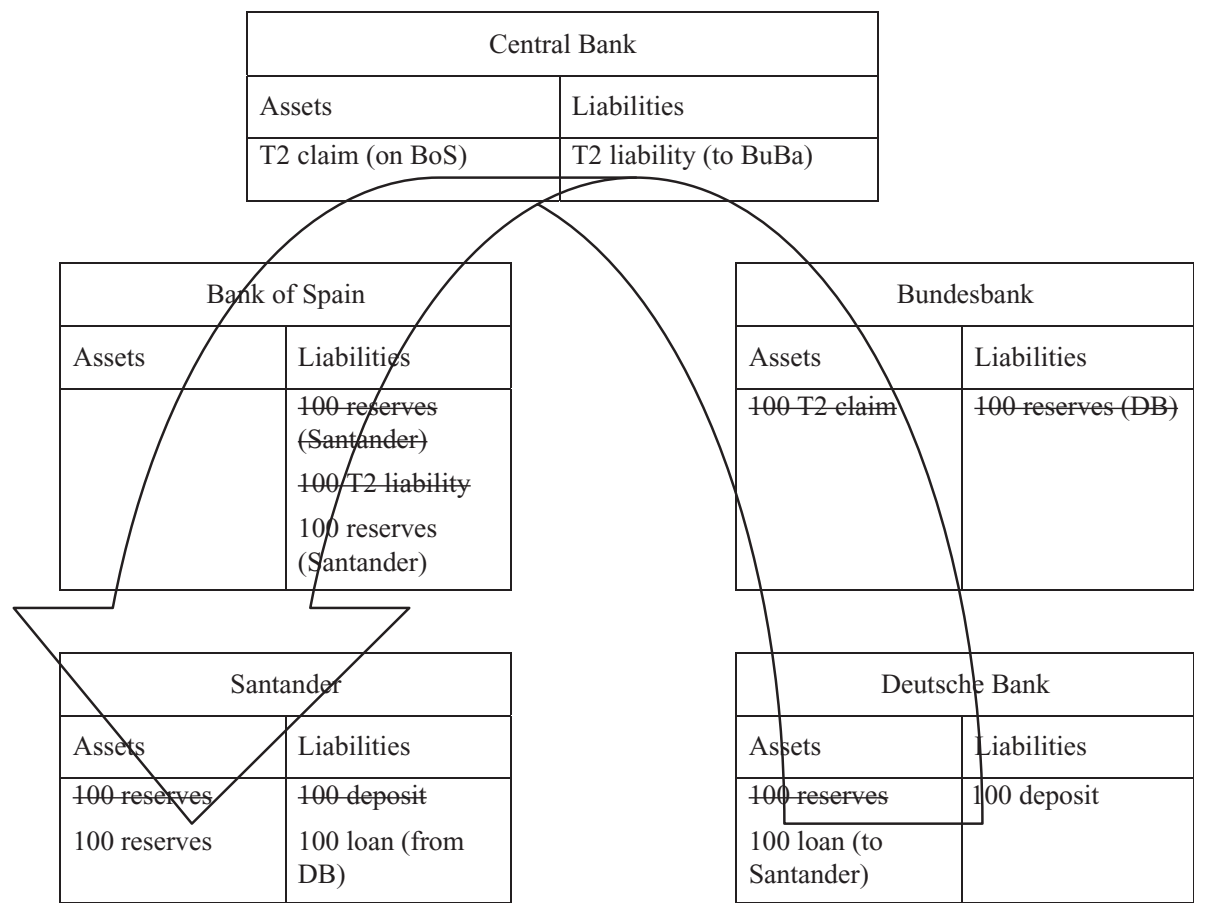

Figure 4 Operation of TARGET2 - step 2 (ante-crisis case)

In a normally functioning CU, as in a FERR, CA deficit countries are financed by private loans from surplus countries (supposing for simplicity that the $\mathrm{CU}$ is a closed entity). In a FERR, however, failure to obtain foreign loans (or worse, capital reversals) for lack of foreign reserves necessarily leads to some sort of adjustment of the CA, whereas in the EMU it is not so. On the one hand, net foreign payments are just accounting records in ECB books, so that T2 is more like a clearing house, while actual payments are settled by the NCB of the surplus country. ${ }^{14}$ On the other hand, creation of reserves in the surplus country is counterbalanced by destruction of reserves in the deficit country. These reserves can be recreated by the local NCB and, unlike in a FERR, these reserves can be used to make further foreign payments (in a CU the distinction between domestic reserves and foreign exchange reserves is blurred). Can this capacity be used ab libitum? In principle the capacity is quite ample, as

14. As pointed out by Kooths/van Roye (2012: 15-16): 'From an accounting perspective, the ECB reduces to a clearing house for cross-border payments. Remaining balances are recorded in the NCBs' balance sheets as changes in their net position with the Eurosystem ("Intra-Eurosystem claims/liabilities"). While cashless transactions affect the "Claims/liabilities on/towards the Eurosystem related to Target2", transactions in cash are recorded as "Claims/liabilities related to other operational requirements within the Eurosystem". From a BoP perspective, changes in the net position with the Eurosystem correspond to a member country's reserve account with respect to the rest of the EMU. If the EMU was a fixed exchange rate regime, positive (negative) Target2-balances and net cash inflows (net cash outflows) would reflect inflows (outflows) of currency reserves, i.e. a reserve account deficit (reserve account surplus)'. 


\begin{tabular}{|l|l|}
\hline \multicolumn{2}{|c|}{ Central Bank } \\
\hline Assets & Liabilities \\
\hline T2 claim (on BoS) & T2 liability (to BuBa) \\
\hline
\end{tabular}

\begin{tabular}{|c|c|}
\hline \multicolumn{2}{|c|}{ Bank of Spain } \\
\hline Assets & Liabilities \\
\hline $\begin{array}{l}100 \text { loan to } \\
\text { Santander }\end{array}$ & $\begin{array}{l}100 \text { reserves } \\
\text { (Santander) } \\
100 \text { T2 liability } \\
100 \text { reserves } \\
\text { (Santander) }\end{array}$ \\
\hline & inder \\
\hline Assets & Liabilities \\
\hline 100 reseryes & $\begin{array}{l}100 \text { deposit } \\
100 \text { loan from } \\
\text { BoS }\end{array}$ \\
\hline
\end{tabular}

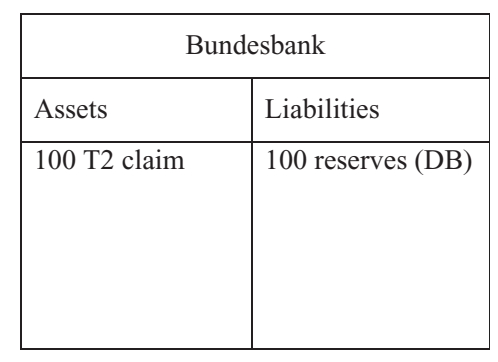

\begin{tabular}{|l|l|}
\hline \multicolumn{2}{|c|}{ Deutsche Bank } \\
\hline Assets & Liabilities \\
\hline 100 reserves & 100 deposit \\
& \\
& \\
\hline
\end{tabular}

Figure 5 Operation of TARGET2 - step 2 (post-crisis case)

long as the country has enough eligible collateral to access the RO and the eligibility criteria set by the ECB or by the NCBs (in the case of Emergency Liquidity Assistance, which still has to be approved by the ECB) are loose enough (for example, Cecioni/Ferrero 2012: 24). Collateral rules have been relaxed by the ECB since 2008. Moreover, Lavoie (2011: 24) and Tornell/Westermann (2012) note that, should NCBs run out of suitable collateral, national governments could issue more bonds and sell them to private banks. These bonds could then be used as collateral to borrow from their NCBs. Tornell/Westermann (2012) conclude that this process 'may face a political limit'. In this regard, Whelan (2013b: 21-22) notes that the ECB may grow reluctant to provide loans to banks in crisis countries that may be insolvent. For instance, the ECB declined to allow further provision of emergency liquidity to Cypriot banks. This move was followed by private sector involvement. The Cypriot case is, however, very specific and it is hard to think that the ECB would show the same reluctance in the cases of Spain or Italy.

There is some analogy between T2 and Keynes's International Clearing Union (ICU), which Keynes regarded as an extension of the principles that govern a national banking system, the same concept that informs T2 (Cesaratto 2013a: 123). In 1941 he even called it 'Currency Union' (Keynes 1980: 44). Like an ICU, the combination of $\mathrm{T} 2$ and ROs (T2/RO hereafter) can be regarded as a recycling mechanism of idle national surpluses (funds nations themselves are not lending), with RO in euros and not in Bancor. But Keynes was more cautious than the designers of the EMU. 
While reserve recycling would give respite to deficit countries, to avoid mounting imbalances they could be asked to devalue or to adjust domestic demand, and surplus countries to sustain domestic credit and demand, revalue or, alternatively, increase money wages (Keynes 1980: 45). Exchange rates adjustments are inapplicable to the EMU, while others are neglected as those concerning surplus countries, although the EU Commission pays official lip service to the monitoring of excess trade surpluses. This is true despite the downward spiral of 'internal devaluation' leading to bottomless 'balance sheet recession' (Koo 2012) that results from austerity policies in deficit countries. The failure of 'expansionary fiscal retrenchment' policies would leave fiscal and nominal wage reflation in surplus countries - assisted by an accommodating monetary policy, fiscal transfers and a genuine banking union - as the only EZ crisis resolution mechanism. Unfortunately, this is precisely the solution that surplus countries do not want to embrace (the reasons for German resistance are explored in Cesaratto/Stirati 2010 and Cesaratto 2011).

\section{THE ECONOMIC ORIGIN OF THE T2 IMBALANCES: FLOW AND STOCK INTERPRETATIONS}

Debate on T2 has revealed two sources of the increasing T2 imbalances of smaller peripheral countries since 2008 (Greece, Ireland and Portugal) and of larger ones since spring 2011 (Italy and Spain) (see Cecioni/Ferrero 2012 and Cecchetti et al. 2012 for periodisation):

(i) persistent CA deficits of peripheral countries that core EZ private banks decline to finance (according to the 'normal times' modalities described above in Section 3);

(ii) an upsurge in capital flight from the periphery to core countries basically due to fear of euro break-up (the 'convertibility risk' of Draghi).

Cecchetti et al. (2012: 1) classified the two sources as flow and stock interpretations of T2 imbalances. This classification reminds us of the difference between sudden stops and reversals of capital flows (Merler/Pisani-Ferry 2012; Deutsche Bank Research 2011). The two interpretations are not antagonistic because they refer to the same phenomenon: in flow terms, to the refusal of core EZ banks to finance further (post-crisis) peripheral CA deficit; in stock terms, to the repatriation of previous loans that financed former (pre-crisis) CA deficits (Febrero/Uxo 2013: 10).

Nonetheless, a number of economists have dismissed (i) as the major cause of imbalance (for example, Buiter et al. 2011; De Grauwe/Ji 2012a; 2012b: 5; Whelan, 2013a: 2, 19-20). While this might to a certain extent be true - CA deficits after 2008 certainly cannot explain the T2 surge - the question is whether or not periphery-tocore capital flight reflects the refusal of core lenders to roll-over past loans that financed past peripheral CA deficits. De Grauwe/Ji (2012b: 10, 14; 2012a), for instance, do not seem very consistent when they (correctly) blame Germany for having pursued persistent trade surplus and accumulation of a huge positive IIP as the ultimate cause of T2 imbalances, while denying that the refusal to roll-over past credits was a source of $\mathrm{T} 2$ imbalances.

According to Mody/Bornhorst (2012), bilateral current CA and capital account imbalances are not strictly correlated; conversely Berger/Nitsch (2012) found a good degree of matching. One difficulty is that financial flows take complicated paths. For instance, Sinn (2012: 4), probably defending German banks against the 
accusation of risky behaviour, argues that German banks lent to French banks (and not directly to the EZ periphery). Chen et al. (2012: 3-4) points out that Germany even intermediated capital flows from China and other extra-EZ countries towards EZ peripheral countries. Considering accumulated CA imbalances, Dullien/Schieritz (2012) and Auer (2013: 32-3) confirm the concurrency of repatriation of German private funds lent before the crisis to the periphery and expansion of German T2 claims along with the support of further CA deficit during the crisis. Capital flight by residents is generally dismissed as a source of T2 imbalances in the major cases of Italy and Spain (Cecioni/Ferrero 2012: 20; Credit Suisse (2012: 4). Sinn (2012: 8) expresses a similar opinion and De Grauwe/Ji (2012c) finally seem to concur. The economic meaning of what happened is ably summed up by Deutsche Bank (2011):

Thus [through T2], the Bundesbank not only financed Germany's current account surplus, replacing earlier private capital flows, but also net capital imports into Germany - to a large extent owed to the repatriation of German investments abroad. Associated with this change in lending patterns was also a big transfer of credit risk from the private banking sector to the Bundesbank.

This statement, precious since it comes from an unsuspicious source, stresses the role of T2 in permitting prolongation of the German export-led model, even when previous loans are withdrawn. In this sense, T2/RO saved German banks from likely default resulting from debtors leaving the euro, by shifting credit risk onto the shoulders of the whole eurozone (not solely the $\mathrm{BuBa}$ ), with some serious limits, as I will later show. ${ }^{15}$ De Grauwe/Ji (2012b: 10; 2012a; 2012c) have pointed out that Germans can only blame themselves for this blind accumulation of foreign claims, ${ }^{16}$ which in Ramanan's words has become 'a Mercantilist's nightmare' (Ramanan 2011).

\section{T2/RO AND THE BANKING AND SOVEREIGN CRISIS}

As clarified above, T2 imbalances and the Eurosystem RO are two sides of the same coin (Garber 2010; JKH 2012: 2-4; Auer 2013: 8, 12, 16; ECB 2013: 107-108; Thimann 2013). Both T2 and RO are part of the monetary policy conducted through the Eurosystem. Although the ECB manages the system in a decentralised way through NCBs, it nevertheless rules this somewhat anarchic, nation-based system of liquidity creation (Cecioni/Ferrero 2012: 23). With regard to banks, the objective of the Eurosystem is twofold (Febrero/Uxò 2013: 21). First, to keep the payment system alive, since if a euro deposited, say, in Portugal, cannot be transferred, say, to France, it would mean the break-up of the monetary union. Second, the RO aim to preserve transmission of monetary policy in the EZ, since interest rates left to the vagaries of the financial markets tend to diverge, especially in a financial crisis (Cecioni/Ferrero 2012: 8). ${ }^{17}$

15. T2 losses are shared by all the EZ NCBs according to their respective stakes in ECB capital. 16. The conventional justification for the persistent German trade surpluses refers to ageing of the German population and to the alleged need to build a stock of foreign assets. Cesaratto/Stirati (2010: 13) show that German mercantilism was evident well before the emergence of the ageing question. Moreover, the crisis is showing the practical fragility of this accumulation of foreign assets. Cesaratto (2005: 212-222; 2006; 2007) discusses foreign investment in relation to ageing and pensions. .

17. Despite the availability of cheap liquidity, the situation of peripheral banks is such that interest rates on loans are much higher than in core-countries, aggravating the competitive gap and leaving the peripheral economies trapped in a credit crunch. Indeed, interest rates on bank loans tend to closely follow sovereign interest rates. 
In theory, monetary targets mainly concern the private financial sector, since the EMU deliberately leaves determination of the interest rate on sovereign bonds to the markets. However, while credible ('big bazooka') outright intervention would have been more effective, long-term RO (particularly LTRO2 in December 2011) were also used by the ECB to prevent Italy and Spain from following in the footsteps of smaller peripheral countries, unable to sell their sovereign bonds at reasonable interest rates, by encouraging peripheral banks to refinance sovereign debts that core EZ banks refused to roll-over. Thus, the combination of T2, which permitted the repatriation of funds, and liquidity-provision operations, which allowed the refinancing of peripheral sovereign debts, avoided a euro-bust (Cecioni/Ferrero 2012: 9; Cecchetti et al. 2012: 9; Whelhan 2013b: 26-27). In this sense, Sinn $(2011$; 2012) is correct in saying that the ECB monetary policy avoided a BoP crisis. Therefore, Sinn's view cannot be dismissed as Febrero/Uxò do, by arguing: 'the refinancing loans (MRO and LTRO) to Spanish banks are not a separate, voluntary monetary policy of the ECB, but the logical consequence of aiming at keeping a uniform very short term interest rate for the whole EZ and running a smooth settlements system' (Febrero/Uxò, 2013: 18-19, their italics). This opinion is shared by many, including the ECB (for example, ECB 2013a; Bindseil/König 2012; Whelan 2013a: 18). While this view is certainly correct, voluntarily or otherwise (which is irrelevant), the ECB action has also de facto procrastinated a BoP crisis (Auer 2013: 35). I agree, of course, that Sinn is plainly wrong in playing down the catastrophic outcome of the crisis had the ECB not taken action. Moreover, this action can keep the crisis at bay, but cannot fix the structural solvency problems of local banks and government.

In a FERR, a country which is losing reserves either lets its currency fluctuate or uses monetary and fiscal policies to reduce domestic demand, or both. In the EMU, if a country is losing reserves (since private banks from the surplus countries are not lending them anymore or are withdrawing former loans), this loss appears as a T2 liability while RO reconstitute the lost reserves. This clearly avoids a liquidity problem in peripheral countries (banks are never short of liquidity), but not the solvency aspect. Recall the protracted Spanish growth period led by a construction boom (for example, Febrero/Bermejo 2013). This was supposedly kept alive by a sequence of new 'vintages' of households that had access to mortgages, but probably lowered the quality of loans (as happened in the US). The prolonged expansion allowed households to remain solvent, as well as Spanish banks, although increasingly indebted to foreign banks. Unfortunately, due to the faster growth of AD relative to core countries and to a real exchange rate revaluation in a structurally catching-up economy, successive CA deficits led to an increasing foreign debt-GDP ratio. Once the construction bubble came to an end and income flows to the families began to suffer, then many loans became non-performing, and the solvency of the bank sector was threatened (in spite of the banks' attempts to hide the problem by reprofiling bad loans). When the Spanish State bailed out the banks, part of the problem was transferred to the State, in a lethal embrace between banks and the State, the so-called 'doom loop' between bank and sovereign crisis (Veron 2013).

The 'doom loop' - the bail-out of local banks by member states followed by the bail-out of member states by local banks - has led to the 'Balkanisation' of sovereign debts in the sense that ownership of peripheral sovereign debts has increasingly (and dramatically) gone back to being national. However, the net IIP of countries has not changed: direct foreign financing has been substituted by T2 claims/liabilities. Garber (2010) complains that this way 'a sovereign debt crisis in one of the euro-zone sovereigns can become a problem for the euro currency and a risk that might overwhelm 
the capital of the ECB'. This is wrong, since - as he would certainly admit - foreign claims/liabilities have simply changed hands, so the risk has remained the same or indeed fallen, since an early bust of the EZ was avoided (De Grauwe/Ji 2012c; Febrero/Uxò 2013: 20)..$^{18}$

Sinn-Garber's further argument is that the T2/RO safety belt postponed the necessary adjustment of imbalances. They are, of course, over-optimistic about the long-run rebalancing effects of competitive deflation policies. Even admitting strong social resilience to harsh policy measures, this strategy ignores its devastating effects on the European and global AD - and also on aggregate supply, through destruction of productive capacity and skills. In truth, no fiscal adjustment is possible without outright support by the ECB, reflation in core countries, larger fiscal transfers and a genuine banking union. Indeed, the ECB-sponsored Balkanisation of sovereign debts has not been an efficient instrument since sovereign spreads are still high, reflecting the devaluation risk due to lack of a reliable ECB guarantee. Indeed, in September 2012 the ECB's mere announcement of Outright Market Transactions consisting of direct intervention in the secondary sovereign bond market was much more effective (Cesaratto 2013b). The limited return of confidence also contributed to a fall in German T2 claims from the $€ 750 \mathrm{bn}$ record (August 2012) to $€ 588$ bn (March 2013) (source: Eurointelligence, 9 April 2013). Of the three pillars of a genuine banking union (IMF 2013) - a single surveillance mechanism and a single resolution mechanism supported by a single resolution fund - only the first has so far been adopted, and there is strong resistance to the remaining two. Most of the crisis resolution costs will probably remain on the shoulders of domestic public and private sectors with no common European safety pool (The Economist 2013).

\section{IS T2 AN INVOLUNTARY SEMI-OFFICIAL TRANSFER OF GERMAN RESERVES TO DEFICIT COUNTRIES?}

Since the T2 question was raised by Sinn, its economic nature has been the subject of lively controversy. In particular, Sinn presented T2 and the accompanying RO as a device by which CA surplus countries unintentionally lend excess reserves to deficit countries. Although T2 and RO are formally detached, it is as if the RO transform the T2 claims of surplus countries, which are a sort of virtual deposit of official reserves, into loans to deficit countries. T2 liabilities can thus be seen as a loan of surplus countries' official reserves - JKH (2012: 18), for instance, interprets T2 balances as a 'higher order' form of reserve, analogous to official reserves in a FERR - or 'similar to creating foreign exchange reserves for the country that is suffering the balance of payment crisis' (Cecchetti et al. 2012: 6). A number of authors share this view, either openly (Deutsche Bank Research 2011; Fahrholz/Freytag 2012; Cour-Thimann/Winkler 2013: 31-32) or de facto (Cecioni/Ferrero 2012: 24). CESifo (2012) compares favourable and unfavourable views. Cecchetti et al. (2012: 4) usefully refer to the BoP identity as:

$$
\text { Current account }+ \text { Capital Account }(K A)+\text { Official Settlements Balance }(O S B) \equiv 0 \text {. }
$$

18. Sinn (2012) retorts that T2 claims have less certain legal status than foreign ownership titles (such as bonds, shares, etc.) in the case of a euro-breakup. Although I believe that in this case T2 net claims would be renegotiated and therefore at least partially redeemed, Sinn has a point. As to the loss of a central bank's capital, I fully endorse Whelan's (2012) and others' points of view that it is an irrelevant concept (see Febrero/Uxò 2013: 20 on this point). 
In short, in a FERR, CA deficits can be financed either by foreign loans (KA), or by depleting official reserves, or by official loans (the last two included in the OSB). If OSB is insufficient, the country has to adjust otherwise. Capital reversals not only mean that $\mathrm{KA}$ inflows do not offset CA deficits, but that there are net outflows, so the burden on OSB is even larger. In the EMU, the OSB adjusts any imbalance in CA and KA in a semi-automatic way through $\mathrm{T} 2$ and generous RO. The analogies between the recycling of reserves in the EMU and Keynes's proposal of an ICU corroborates the view of $\mathrm{T} 2 / \mathrm{RO}$ as a quasi-OSB. As seen, this recycling not only concerns new CA imbalances, but also repatriation of previous private loans that surplus countries granted to deficit countries. The decentralised management of the Eurosystem may give the impression that peripheral countries are self-bailing-out, since the RO are conducted by NCBs. In actual fact - as we observed above - what happens is implementation of the EMU monetary rules, but it is also de facto consistent with Sinn's view of a stealth bail-out. ${ }^{19}$ It is clear, however, that T2/RO is not the cause of the EZ imbalances, but the effect. Paradoxically, the same (often German) authorities that denounce what might look like relentless mounting of T2 imbalances also oppose measures such as those advocated by Keynes to solve them when he proposed the ICU.

\section{THE NATURE OF CAPITAL FLOWS: INTERNATIONAL LOANABLE FUNDS OR ELSE?}

The T2 debate also has interesting implications for interpretation of international capital flows in the EZ crisis. According to neoclassical theory, international financial flows are an expression of the time-honoured loanable funds theory, by which loanable funds are the practical manifestation of the savings supply. In the case of international loanable funds, they represent savings from capital-rich countries - with a lower natural interest rate, $i_{n}^{\text {core }}$ - that become available to countries with lower capital endowment - and a higher natural interest rate, $i_{n}^{p}$. So the divergence between natural interest rates, $i_{n}^{p}-i_{n}^{\text {core }}>0$, justifies a view of capital movements as a general equilibrium phenomenon (Blanchard/Giavazzi 2002). Applied to the EZ crisis, the standard neoclassical interpretation is that German savers loaned to peripheral countries - savings being equal to the CA surplus according to the well-known national account identity (where the German CA balance is simplified in the trade-balance component, in standard notation):

$$
S_{G}-I_{G}=\left(G_{G}-T_{G}\right)+\left(X_{G}-M_{G}\right) .
$$

From a logical (and endogenous money) point of view it is unclear how German savers could lend abroad before Germany's trade-surplus materialises. Indeed, the T2 story makes it clear that the financial circuit begins with a loan granted in, say, Spain (cf. Febrero/Uxò 2013: 3-4). Suppose that autonomous spending in Spain consists of residential investment $\left(I_{S}\right)$ financed by loans (overdraft deposits) given by Santander (I ignore government and assume zero exports for simplicity). During the income

19. Febrero/Uxò (2013: 22) conclude that: 'T2 imbalances are not new loans, but the defensive outcome of a central bank aiming at steering a payment system smoothly, and at granting access to all banks within the monetary union under equal conditions. Without refinancing loans, provided by NCBs, private banks in the EZ periphery could not comply with the reserve requirement and the monetary transmission mechanism would not work at all'. Apart from the fact that they could also be 'new loans', whatever the official motivations of the ECB, the authors cannot deny Sinn's point that, in the end, a loan is a loan is a loan. 
multiplier process, deposits change hands, and at each step part of the income is consumed or saved, and part spent to import, depending on the respective marginal coefficients (Dalziel 1996). At the end of the process the following equation applies to Spain:

$$
I_{S}-S_{S}=M_{S}
$$

That is, imports correspond to that part of the (residential) investment that is not financed by domestic savings. In financial terms, payments for imports that mature during the income multiplier process are channelled through T2 to (say) German exporters. Supposing, again for simplicity, that exports are the only autonomous component of AD in Germany, and assuming no public administration and zero propensity to import, German savings are equal to net exports - that is:

or, given that $M_{S}=X_{G}$,

$$
S_{G}=X_{G}
$$

$$
S_{G}=I_{S}-S_{S}{ }^{20}
$$

In financial terms, if $S_{G}$ is deposited at $\mathrm{DB}$, then it corresponds to the loan that Santander obtains from DB (in normal times) on the inter-bank loan market (see Section 3). So, ex post (and only ex post), Germany is lending 'savings' to Spain; not ex ante, as in the standard loanable fund theory.

A more generous interpretation of the neoclassical view would not, however, regard it as inconsistent with the endogenous money view and lend itself to a better understanding of Sinn's views. Interpreting the theory along Wicksellian lines, the 'one size fits all' EZ interest rate policy along with the (temporary) disappearance of the exchange rate risk and a higher local inflation rate would entail that, in the period 1999-2007, the (real) market interest rate had been below the Wicksellian natural rate in the periphery, $i_{m}^{p}<i_{n}^{p}$ (while in core Europe it had presumably been higher, $i_{m}^{\text {core }}>i_{n}^{\text {core }}$ ). Credit demand would therefore have been encouraged in the periphery (and discouraged in the core), causing over-expansion of local credit, trade imbalances and capital flows from core Europe. ${ }^{21}$ This sort of reasoning is presumably behind Sinn's (2013) recurring complaint that 'Germany, under the euro, was the largest capital exporter and plunged into a deep slump. Only one-third of its savings was invested at home. As a result, during the early years of the euro, its net investment and growth rates were the lowest in Europe.' Clearly, in Sinn's view, core-periphery capital flows went far beyond the equilibrium phenomenon envisaged by Blanchard/Giavazzi (2002).

This more generous account of the neoclassical view reminds us that endogenous money is not an ultimate criticism of this theory (Pivetti 2001), which should, rather, be based upon criticism of the concepts of natural and market interest rates (for example, Stirati 2001) and of neoclassical trade and capital-movement theory (Cesaratto 2013a: 111-114; Cesaratto 2012e: 12-14), in favour of Frenkel-style

20. A simple numerical example might help. Suppose that autonomous spending is $I_{S}=€ 100$ and the Spanish marginal propensity to save and import is $s=0.2$ and $m=0.2$, respectively. Spain's income is $€ 250$ and $S_{S}=I_{S}=M_{S}=€ 50$. Assuming $s=0.2$ and $m=0$, German income is $€ 250$ and $S_{G}=€ 50$.

21. As two German neoclassical economists argue, the expansion of loans that activated the circuit has been favoured by belief 'in a successful economic convergence process at the outset of the EZ membership'; the outcome has been 'a fall in risk premia from the perspective of the private financial sector' and a fall in 'the financing cost of the periphery' (Fahrholz /Freytag, 2012: 9). 
(Diaz-Alejandro 1985; Frenkel 2013) and Classical-Kaleckian accounts of the events (Cesaratto 2013a; 2013b; Lucarelli 2012).

As an aside, but quite relevant for the policy debate, if it was credit created in the periphery that generated saving in core EZ countries, in the same vein fiscal transfers to the periphery should not be seen as a drain on (say) German resources, but as the source of those resources. Let us take for granted the MMT proposition that the State spends before collecting taxes or issuing bonds (see Lavoie 2011 for discussion), then any federal transfer-spending in favour of depressed areas will generate demand in favour of stronger areas. Although most taxes and government bond sale revenues will accrue from the latter regions, they will still benefit from larger income, what Barba/De Vivo (2013: 17, 22) call a 'growth dividend mechanism'. Of course, taxpayers in the most affluent areas will not collect (risky) financial claims on the poorer regions. But this would avoid potential financial crisis and painful AD and CA adjustments. In this regard, an inter-regional tax-transfer scheme is more stable, politically and financially. Lamentably, it is unlikely that this argument would convince many European economists or politicians, let alone German public opinion.

\section{T2 AT THE TIME OF A EURO BREAK-UP}

Many economists have pointed out that although Werner Sinn's denunciation of the risks that Germany is running with its increasing T2 surplus balance is mixed with false arguments, ${ }^{22}$ he is not basically wrong. Other economists, however, play down these risks. Two German progressive economists, Dullien/Schieritz (2012), for instance, argue that German repatriation of private funds from the periphery, substituted by T2 claims, should be applauded by the German public since it implies euro-socialisation of the risk of default at EZ level, which benefits by far the largest claimant most. The question is that core EZ countries are sharing their T2 risk with the same debtor countries: a vicious circle would emerge if several countries including major ones defaulted in their liabilities (JKH 2012: 27-28).

The distinguished Irish economist Karl Whelan (2012), endorsed by the LSE economist Paul De Grauwe (De Grauwe/Ji 2012a; 2012b: 12), uses another argument to maintain that $\mathrm{T} 2$ credit countries would not incur any specific loss, even in the case of a euro break-up. Briefly, they argue that in principle a CB can bear any loss on its assets because it owns the printing press - that is, in a fiat-money regime the $\mathrm{CB}$ can issue money not backed by any tangible asset (this specific point is, of course, true). In the case of a euro break-up, the Bundesbank would redenominate all its liabilities (monetary base) in, say, neu-DM, along with redenomination of deposits and domestic contracts. Even in the extreme case of losing all its T2 claims, this loss would mean nothing to the ordinary German citizen who would hold banknotes or deposits in neu-DM. Any euros are replaced one-to-one by neu-DM. ${ }^{23}$ Equally easily, the Bundesbank could recapitalise itself by buying special Treasury bonds with newly printed money, money that the Treasury could then use to recapitalise the BuBa without

22. For instance that foreign lending displaced home investment in Germany (cf. Section 7 above).

23. For instance De Grauwe/Ji (2012b: 11) argue: 'In the fiat money system we live in, the Bundesbank could destroy all its assets without any effect on the value of the money base as long as people continued to trust the Bundesbank to maintain price stability. Economists who are confused on this point are usually thinking about central banks in gold-standard terms. Back then the central bank's assets (gold) had a very direct impact on the value of the monetary base - after all, the central bank promised to back paper money with gold. The 
cost to the taxpayer (Whelan 2012; Febrero/Uxò 2013: 20). It was too easy for Sinn to demolish these arguments. Indeed, he fully endorsed the view that the 'central bank could ... destroy its assets without reducing the value of the monetary base' (Sinn 2012), but this does not entail that 'the central bank in question and the sovereign that owns it would not incur wealth losses if it destroyed its assets'. This is so because the $\mathrm{CB}$ would lose the seignorage flowing from T2 net claims (at a rate equal to that of the ECB's main refinancing operations), which is part of the net foreign income flow of the current account and, therefore, part of the GNP (= GDP + net foreign income). ${ }^{24}$ While Whelan (2012) would acknowledge this, he also argues that any loss can also be accommodated by the Bundesbank, which can continue to pay the same interest on deposits by printing money - and, anyway, it would not be a large loss in terms of German GDP, since resulting revenues are shared within the Eurosystem (Whelan 2013a: 9). While this may be true, this view entails that a country can lose foreign assets and income without much problem (Ramanan 2012b). ${ }^{25}$ Significantly, De Grauwe/Ji (2012c), in their final reply to Sinn (2012), dumped Whelan's arguments, relying on the most solid criticism to the German 'conscious policy of accumulation of current account surpluses vis-à-vis the rest of the Eurozone, especially during the period before the debt crisis', adding that 'if a breakup were to materialise, this will lead to losses for Germany, independently of the existence of TARGET2. Germany could have avoided this by reducing its current account surpluses; it refused to do so and thus the responsibility for this risk is Germany's, and not some obscure system like TARGET2.'

\section{MAIN RESULTS}

1. In a flawed $\mathrm{CU}$, the absence of convertibility risk, financial liberalisation and a loose 'one size fits all' monetary policy possibly associated with mercantilist behaviour of more competitive partners may encourage less competitive members to become indebted to members who are better off. This occurs because local credit-financed

ECB (and most central banks of large developed countries), however, has made no such promise. The value of its liabilities, therefore, is not dependent of the value of the assets it holds'. Felix Salmon (2012) popularised Whelan/De Grauwe's view.

24. 'Although a country's monetary base would retain its value after a breakup of the euro and a conversion to national currency, it would not be irrelevant if a country's TARGET claims are destroyed, since they represent the present value of a flow of seignorage stemming from other countries' commercial banks that compensates for prior outflows of goods, assets, and debt certificates to these countries. An interruption of the flow of seignorage from foreign commercial banks would imply real wealth losses for the surplus country's taxpayers and/or savers' (Sinn 2012).

25. In lively blogosphere discussions, the various bloggers tried in vain to convince Whelan on these points. I found comments by Ramanan and JKH in the discussions after Whelan (2011) and Salmon (2012) particularly instructive. They both point out that a loss of T2 net claims and income is a real loss that cannot be substituted by printing neu-DM. Otherwise, why should a country bother to export, or be paid. As one witty anonymous blogger summed up: 'Professor Whelan's response seems to boil down to this: If the Eurosystem fails, the German taxpayers won't feel a thing because their central bank will replace that receivable from the defunct Eurosystem with its own newly-created local currency. By that logic, Germany should immediately ramp up its dishwasher (and other goods) production and export to the rest of the world without worrying about the rest of the world's ability to pay, because the Bundesbank will cover any losses via printing press. Really?' (comment to Salmon 2012). 
autonomous spending does not generate enough domestic savings. In a viable CU, external indebtedness is discouraged by fiscal transfers, and crisis resolution mechanisms are in place. In a flawed $\mathrm{CU}$, the absence of friendly federal crisis resolution mechanisms might tempt deficit countries to leave the CU. Mechanisms such as T2/RO prevented the BoP crisis from spiralling as it would have done in an FERR, however they cannot fix a solvency problem made worse by 'convertibility risk'.

2. Since 2009 for PIGs, and hugely since 2011 for Spain and Italy, foreign investors have refused to roll-over (re-finance) previous debt that financed past CA deficits. Therefore, growing T2 imbalances not only reflect the need to finance persisting CA deficits of the periphery but, more importantly, the need to accommodate capital flight from periphery to core countries.

3. Sinn (for example 2011 ; 2012) is right in regarding $\mathrm{T} 2 / \mathrm{RO}$ as automatic refinancing of the $\mathrm{BoP}$ of CA deficit countries, although he systematically overstretches his argument with implications aimed at depicting Germany as the victim, a view that the literature (including Whelan and De Grauwe/Ji) has shown to be wrong. Combining the two aspects (that is, the creation of persistent credit-liability positions by $\mathrm{T} 2$ and the increasing borrowing of periphery countries from their NCBs), it is as if the very reserves lent by German private banks when confidence prevailed, now deposited at the ECB, are now lent by the ECB through the NCBs, by virtue of the decentralised management of the RO in the Eurosystem. The net IIP of Germany (Spain) is the same, but now Germany (Spain) is (automatically) lending (borrowing) through T2, while BoS creates liquidity, although this operation is formally separate from the emergence of T2 unbalances ("two sides of the same coin'). If this combination did not exist, however, the entire bank system would break down. Thus Sinn is not wrong to call T2 a 'stealth bail-out' of the periphery, although he is silent about German responsibilities in this crisis for what has been called a 'vendor finance' scheme, and he forgets that 'stealth bail-out' also concerns the lender side (that is, German banks). Of course, T2 can only fix some liquidity problems of the periphery, and cannot ensure solvency of states and banks. Core EZ countries should thank T2/RO for giving the EZ more time to fix the situation. Unfortunately, this time has so far been wasted (Cesaratto 2013b). While no deep reforms of the institutional and financial architecture of the EZ have been attempted, the EZ, encouraged by a wrong diagnosis of the crisis, has pursued painful adjustment through austerity and competitive deflation, unsuccessful in economically rebalancing Europe and restoring growth, and that might prove politically unsustainable given its devastating social costs.

4. In view of the above, $\mathrm{T} 2$ can be interpreted as a CA surplus recycling device in favour of deficit countries, something that recalls Keynes's proposal of an ICU. Not only can T2 accomplish the recycling of current deficits, but it can also fix capital flight (repatriation of early loans that financed previous CA deficits) from indebted countries, transforming, as we have seen, private loans into 'official' T2 loans. In principle, T2 may substitute the private financing and roll-over of deficit countries almost ad libitum, but there are of course limits to what Minsky defined as 'Ponzi finance'. The austerity measures imposed by the EU on indebted countries may thus be seen as a way - unfortunately neither effective nor socially sustainable - to generate CA surpluses so as to guarantee servicing and possibly reduction of their net foreign debt. On the other hand, Keynes's proposal emphasized the need for expansionary adjustment by surplus countries. 
5. It is untrue that a breakdown of the Eurosystem would be without consequences for the net financial wealth and income of surplus countries. T2 claims are part of the IIP of a country and the interest flows are part of the GNP. In the case of a euro break-up, negotiations will likely include the destiny of T2 balances. Deficit countries will probably not renege on all their liabilities, especially not interest payments on former T2 liabilities (Whelan 2013a: 33-34). Be that as it may, it was easy for Werner Sinn (2012) and others to demolish Whelan-De-Grauwe/Ji's argument that conversion of the denomination of T2 liabilities into, say, neu-DM would fix any problem from the point of view of the German saver. Despite his incorrect diagnosis of the crisis and related policy prescriptions, Sinn deserves the last word.

\section{REFERENCES}

Auer, R.A. (2013): What drives Target2 balances? Evidence from a panel analysis, CESifo Working Paper No 4216.

Barba, A., De Vivo, G. (2013): Flawed currency areas and viable currency areas - external imbalances and public finance in the time of the euro, in: Contributions to Political Economy, 32(1), 73-96.

Berger, H., Nitsch, V. (2012): Bilateral imbalances in Europe, Darmstadt Discussion Papers no. 214, URL: http://www.download.tu-darmstadt.de/wi/vwl/ddpie/ddpie_214.pdf (forthcoming in CESifo Economic Studies).

Bindseil, U., König, P. (2012): TARGET2 and the European sovereign debt crisis, in: Kredit und Kapital, 45(2), 135-174.

Blanchard, O., Giavazzi, F. (2002): Current account deficits in the euro area: the end of the Feldstein-Horioka puzzle?, in: Brookings Papers on Economic Activity, 2002(2), 147-186.

Bordo, M.D., James, H. (2013): The European crisis in the context of the history of previous financial crises, NBER Working Paper, No 19112.

Buiter, W.H., Rahbari, E., Michels, J. (2011): The implications of intra-euro imbalances in credit flows, CEPR Policy Insight no 57, URL: http://www.cepr.org/pubs/policyinsights/ PolicyInsight57.pdf.

Carrión Álavarez, M. (2013): All of Draghi's horses - thoughts on banking union and the Cyprus 'solution', 28 March, URL: www.Eurointelligence.com.

Cecchetti, S.G., McCauley, R.N., McGuire, P.-M. (2012): Interpreting TARGET2 balances, BIS Working Papers, No 393, December, URL: http://www.bis.org/publ/work393.htm.

Cecioni, M., Ferrero, G. (2012): Determinants of TARGET2 imbalances, Questioni di economia e finanza (Occasional Papers), No 136, URL: http://www.bancaditalia.it/pubblicazioni/ econo/quest_ecofin_2/qef136;internal\&action=_setlanguage.action?LANGUAGE=en).

Cesaratto, S. (2005): Pension Reform and Economic Theory: A Non-Orthodox Analysis, Cheltenham, UK: Edward Elgar.

Cesaratto, S. (2006): The saving-investment nexus in the debate on pension reforms, in: Salvadori, N. (ed.), Economic Growth and Distribution: On the Nature and Causes of the Wealth of Nations, Cheltenham, UK: Edward Elgar, 221-245.

Cesaratto, S. (2007): Are PAYG and FF pension schemes equivalent systems? Macroeconomic considerations in the light of alternative economic theories, in: Review of Political Economy, 30, 449-473.

Cesaratto, S. (2011): Europe, German mercantilism and the current crisis, in: Brancaccio, E., Fontana, G. (eds), The Global Economic Crisis: New Perspectives on the Critique of Economic Theory and Policy, London: Routledge, 246-260; working paper version: http://www. econ-pol.unisi.it/dipartimento/it/node/1173.

Cesaratto, S. (2012a): Born in the U.S.A. - MMT and monetary sovereignty, URL: http://www. concertedaction.com/2012/05/06/born-in-the-u-s-a-mmt-and-monetary-sovereignty/. 
Cesaratto, S. (2012b): The spurious victory of MMT, URL: http://nakedkeynesianism.blogspot.it/ 2012/07/spurious-victory-of-mmt.html.

Cesaratto, S. (2012c): A reply to Wray (I), URL: http://nakedkeynesianism.blogspot.it/2012/08/ a-reply-to-wray-part-i.html.

Cesaratto, S. (2012d): A reply to Wray (II), URL: http://nakedkeynesianism.blogspot.it/2012/08/ a-reply-to-wray-part-ii.html.

Cesaratto, S. (2012e): Harmonic and conflict views in international economic relations: a Sraffian view, Quaderni del Dipartimento di Economia Politica e Statistica, n. 651, URL: http:// www.deps.unisi.it/it/ricerca/pubblicazioni-deps/quaderni-deps/anno-2012; forthcoming in Levrero, E.S., Palumbo, A., Stirati, A. (eds), Sraffa and the Reconstruction of Economic Theory, Vol. II: Aggregate Demand, Policy Analysis and Growth, Basingstoke, UK: Palgrave Macmillan.

Cesaratto, S. (2013a): Controversial and novel features of the Eurozone crisis as a balance of payment crisis, in: Dejuán, Ó., Febrero, E., Uxò, J. (eds), Post Keynesian Views of the Economic Crisis and its Remedies, London: Routledge, 111-129; working paper version: http:// www.econpol.unisi.it/dipartimento/it/node/1649.

Cesaratto, S. (2013b): The endless Eurozone crisis, where do we stand? A Classical-Kaleckian overview, Studi Economici, n.2, 2012 (printed in 2013); working paper version: http://www.econpol. unisi.it/ (n.671) e; http://www.networkideas.org/featart/feb2013/fa27_Sergio_Cesaratto.htm.

Cesaratto, S., Stirati, A. (2010): Germany in the European and global crises, International Journal of Political Economy, 40(4), 56-87; URL: http://econpapers.repec.org/article/mesijpoec/\#v40:i4. Working paper version: http://www.econ-pol.unisi.it/dipartimento/it/node/1267.

CESifo (2012): The European balance of payments crisis, in: H.-W. Sinn (ed.), CESifo Forum, 13 , Special Issue January.

Chen, R., Milesi-Ferretti, G.M., Tressel, T. (2012): External imbalances in the Euro area, IMF Working Paper, Sept. 2012, URL: http://www.imf.org/external/pubs/ft/wp/2012/wp12236.pdf.

Cour-Thimann, P., Winkler, B. (2013): The ECB's non-standard monetary policy measures: the role of institutional factors and financial structure, ECB working paper series, no. 1528, URL: http://www.ecb.europa.eu/pub/pdf/scpwps/ecbwp1528.pdf.

Credit Suisse (2012): TARGET2: I'm a euro, get me out of here!, URL: https://doc.research-andanalytics.csfb.com/docView?language=ENG\&format=PDF\&document_id=964947261\& source_id=em\&serialid=fjZBELOflTGqDgVCVfo8\%2BtOvvs9YbG2JziY58\%2BpZdH8\%3D.

Dalziel, P.C. (1996): The Keynesian multiplier, liquidity preference, and endogenous money, in: Journal of Post Keynesian Economics, 18(3), 311-331.

De Grauwe, P., Ji, Y. (2012a): How Germany can avoid wealth losses if the Eurozone breaks up: limit conversion to German residents, Vox, URL: http://www.voxeu.org/article/how-germanycan-avoid-wealth-losses-if-eurozone-breaks-limit-conversion-german-residents.

De Grauwe, P., Ji, Y. (2012b): What Germany should fear most is its own fear - an analysis of Target 2 and current account imbalances, CEPS Working Document No 368, URL: http:// www.ceps.eu/book/what-germany-should-fear-most-its-own-fear-analysis-target2-andcurrent-account-imbalances.

De Grauwe, P., Ji, Y. (2012c): TARGET2 as a scapegoat for German errors, Vox, URL: http:// www.voxeu.org/article/target2-scapegoat-german-errors.

De Grauwe, P., Ji, Y. (2013): Panic-driven austerity in the Eurozone and its implications, Vox, URL: http://www.voxeu.org/article/panic-driven-austerity-eurozone-and-its-implications.

Deustche Bank Research (2011): Euroland's hidden balance-of-payments crisis, October, URL: http://www.dbresearch.com/PROD/DBR_INTERNET_EN-PROD/PROD0000000000279906/ Euroland\%E2\%80\%99s+hidden+balance-of-payments+crisis.pdf.

Diaz-Alejandro, C. (1985): Good-bye financial repression, hello financial crash, in: Journal of Development Economics, 19, 1-24.

Dullien, S., Schieritz, M. (2012): German savers should applaud the growing TARGET balances, Vox, URL: http://www.voxeu.org/article/german-savers-should-applaud-growing-targetbalances.

ECB (European Central Bank) (2013a): Target balances and monetary policy operations, in: Monthly Bulletin, May. 
ECB (European Central Bank) (2013b): Verbatim of the remarks made by Mario Draghi, URL: http://www.ecb.europa.eu/press/key/date/2012/html/sp120726.en.html.

Economist, The (2013): A half-hearted banking union raises more risk than it solves, 8 June.

Fahrholz, C., Freytag, A. (2012): Will Target2-balances be reduced again after an end of the crisis, GFinM, working paper no. 30, URL: http://www.gfinm.de/images/stories/workingpaper30.pdf.

Febrero, E., Bermejo, F. (2013): Spain during the Great Recession: teetering on the brink of collapse, in: Dejuán, Ó., Febrero, E., Uxò, J. (eds), Post Keynesian Views of the Economic Crisis and its Remedies, London: Routledge, 266-293.

Febrero, E., Uxò, J.F.B. (2013): Understanding TARGET2 imbalances from an endogenous money view, Department of Economics and Finance, University of Castilla-La Mancha, WP DT-DAEF 2013/2.

Frenkel, R. (2013): Lessons from a comparative analysis of financial crises, Comparative Economic Studies, 28 February 2013; doi:10.1057/ces.2013.2 (mimeo version: http://www.unich. it/docenti/bagnai/euro/Frenkel.pdf).

Garber, P. (1998): Notes on the role of TARGET in a stage III crisis, NBER Working Paper, No 6619.

Garber, P. (2010): The mechanics of intra euro capital flight, Deutsche Bank Special Report, URL: http://fincake.ru/stock/reviews/56090/download/54478.

Godley, W. (1992): Maastricht and all that, in: London Review of Books, 14(19), URL: http:// www.lrb.co.uk/v14/n19/wynne-godley/maastricht-and-all-that.

Gros, D. (2012a): The single European market in banking in decline - ECB to the rescue? Vox, URL: http://www.voxeu.org/article/single-european-market-banking-decline-ecb-rescue.

Gros, D. (2012b): Banking union: Ireland vs Nevada, an illustration of the importance of an integrated banking system, Vox, URL: http://www.voxeu.org/article/banking-union-if-ireland-were-nevada.

Holinski, N., Kool, C., Muysken, J. (2012): Persistent macroeconomic imbalances in the Euro area: causes and consequences, in: Federal Reserve Bank of St. Louis Review, January/ February: $1-21$.

IMF (International Monetary Fund) (2013): A banking union for the Euro area, IMF Staff Discussion Note, February, URL: http://www.imf.org/external/pubs/ft/sdn/2013/sdn1301.pdf.

JKH (2012): TARGET2 - Window on Eurozone risk, URL: http://pragcap.com/wp-content/ uploads/2012/09/TARGET2-Window-on-Eurozone-Risk.pdf.

Kaldor, N. (1971): The dynamic effects of the common market, in: New Stateman, 12 March.

Keynes, J.M. (1980): Activities 1940-1944. Shaping the Post-War World: The Clearing Union, in: Robinson, A., Moggridge, D. (eds), Collected Writings of John Maynard Keynes, vol. 25. London: Macmillan.

Koo, R.C. (2012): The world in balance sheet recession: causes, cure, and politics, in: Real-World Economics Review, 58, URL: http://www.paecon.net/PAEReview/issue58/Koo58.pdf.

Kooths, S., van Roye, B. (2012): Euro area: single currency - national money creation, Kiel Working Paper No 1787, URL: http://www.ifw-members.ifw-kiel.de/publications/single-currencynational-money-creation/KWP\%201787\%20-\%20Single\%20Currency,\%20national\% 20money\%20creation\%20.pdf.

Lavoie, M. (2005): A primer in endogenous credit-money, in: Rochon, L.-P., Rossi, S. (eds), Modern Theories of Money: The Nature and Role of Money in Capitalist Economies, Cheltenham, UK: Edward Elgar, 506-543 (mimeo version: http://aix1.uottawa.ca/ robinson/Lavoie/Courses/ 2007_ECO6183/childguide4.pdf).

Lavoie, L. (2011): The monetary and fiscal nexus of neo-chartalism: a friendly critical look, IMK Conference, Berlin, URL: http://www.boeckler.de/pdf/v_2011_10_27_lavoie.pdf (published in Journal of Economic Issues, 2013, 42, 1-32).

Lucarelli, B. (2012): German neomercantilism and the European sovereign debt crisis, in: Journal of Post-Keynesian Economics, 34, 205-224.

Merler, S., Pisani-Ferry, J. (2012): Sudden stops in euro area, Bruegel Policy Contribution, URL: http://www.bruegel.org/publications/publication-detail/publication/718-sudden-stops-in-theeuro-area/.

Mody, A., Bornhorst, F. (2012): TARGET imbalances: financing the capital-account reversal in Europe, Vox, URL: http://www.voxeu.org/article/target-imbalances-financing-capital-accountreversal-europe. 
Pivetti, M. (2001): Money endogeneity and monetary non-neutrality: a Sraffian perspective, in: Rochon, L.-P., Vernengo, M. (eds): Credit, Interest Rates and the Open Economy: Essays on Horizontalism, Cheltenham, UK: Edward Elgar, 104-119.

Ramaman (2011): Who is Germany? URL: http://www.concertedaction.com/2011/12/18/who-isgermany/).

Ramanan (2012a): Not a balance-of-payments crisis? URL: http://www.concertedaction.com/ 2012/10/27/not-a-balance-of-payments-crisis/.

Ramanan (2012b): Why Paul De Grauwe is wrong about TARGET2, URL: http://www. concertedaction.com/2012/09/17/why-paul-de-grauwe-is-wrong-about-target $2 /$.

Reinhart, C.M. (2012): A series of unfortunate events: common sequencing patterns in financial crises, NBER Working Paper, URL: http://www.nber.org/papers/w17941.

Salmon, F. (2012): Don't worry about Target2, Reuters, URL: http://blogs.reuters.com/felix-salmon/ 2012/06/14/dont-worry-about-target2/.

Simonazzi, A., Vianello, F. (1999): Liberalizzazione finanziaria, moneta unica europea e occupazione, in: Pizzuti, F.R. (ed.), Globalizzazione, Istituzioni e Coesione Sociale, Catanzaro: Meridiana, 227-253; mimeo version available at: http://www.fernandovianello.unimore.it/ site/home/una-selezione-di-scritti.html.

Sinn, H.-W. (2011): The ECB's stealth bailout, Vox, URL: http://www.voxeu.org/article/ ecb-s-stealth-bailout.

Sinn, H.-W. (2012): TARGET losses in case of a euro breakup, Vox, URL: http://www.voxeu. org/article/target-losses-case-euro-breakup.

Sinn, H.-W. (2013): It is wrong to portray Germany as the euro winner, in: Financial Times, 22 July.

Stirati, A. (2001): Inflation, unemployment and hysteresis: an alternative view, in: Review of Political Economy, 13, 427-51.

Thimann, C. (2013): Banking union should ease Target fears, in: Financial Times, URL: http:// www.ft.com/intl/cms/s/0/a84d3c46-5bb-11e2-8ccc-00144feab49a.html.

Tornell, A., Westermann, F. (2012): Has the ECB hit a limit?, Vox, URL: http://www.voxeu. org/article/has-ecb-hit-limit.

Veron, N. (2013): A realistic bridge towards European Banking Union, Peterson Institute for International Economics, Policy Brief PB 13-17, June.

Whelan, K. (2011): More TARGET2 fun: Bloomberg Edition, URL: http://www.irisheconomy. ie/index.php/2011/12/15/more-target-2-fun-bloomberg-edition/.

Whelan, K. (2012): TARGET2: not why Germans should fear a euro breakup, Vox, URL: http:// www.voxeu.org/article/target2-germany-has-bigger-things-worry-about.

Whelan, K. (2013a): TARGET2 and central bank balance sheets, University College Dublin, Centre for Economic Policy Research, WP12/29 (new draft: March 2013), URL: http:// www.karlwhelan.com/Papers/T2Paper-March2013.pdf.

Whelan, K. (2013b): Sovereign default and the euro, University College Dublin, Centre for Economic Policy Research, WP12/29, URL: http://www.ucd.ie/t4cms/WP13_09.pdf.

Wray, R. (2012): Cross border lending and imbalances in euroland, URL: http://www.economonitor. com/lrwray/2012/10/27/cross-border-lending-and-imbalances-in-euroland/. 